\title{
ADOPTION OF IMPROVED AQUACULTURE PRACTICES BY SHRIMP FARMERS IN SOUTH KONKAN REGION MAHARASHTRA, INDIA
}

\author{
M. M. GAWDE , M. S. CHANDGE, M. M. SHIRDHANKAR
}

\begin{abstract}
To achieve eco-friendly and sustainable development of shrimp farming, adoption of improved shrimp farming practices is necessary. An attempt has been made in this study to collect data from shrimp farmers along the south Konkan region of Maharashtra to judge the level of adoption of improved aquaculture practices. The data was collected by personally interviewing the farmers with the help of questionnaire. Descriptive score sheets for each of the recommended practice was constructed with zero, one and two scores. The adoption quotient obtained by the shrimp farmers ranged from 50 to 96.88 with the mean of 76.18 . It was observed that there was quite high extent of adoption for some of the practices such as use of check trays and adjustment of feed accordingly (95.0\%), formation of bloom in colour range of brownish to yellowish before stocking (92.5\%). It was also seen that there was quite high partial adoption among the shrimp farmers w.r.t. frequent checking of water parameters $(82.5 \%)$, checking of healthiness of seed before packing $(72.5 \%)$.
\end{abstract}

Key words: adoption, improved aquaculture, shrimp farmers

\section{INTRODUCTION}

Indian coastal zone is endowed with natural resources in the forms of brackish water, mud flats, swamps, marshes, lagoons, mangroves, backwaters and estuaries. The total estimated brackish water area is about 1.4 million ha, out of which 1.19 million ha is found suitable for brackish water shrimp farming. Even though India is having such a huge potential brackish water area, only 13 per cent $(1,56,500 \mathrm{ha})$ is developed till March 2003. Maharashtra is gifted with 80,000 ha total brackish water area out of which 14,455 ha is suitable for aquaculture and 871 ha is developed for shrimp culture. The south konkan region is blessed with 2,950 ha area suitable for brackish water aquaculture of which only four per cent (117.83 ha) area is under culture (Lokare, 2002).

Brackish water shrimp farming is getting more attention because of high profitability of this business. But it is necessary to adopt improved aquaculture practices so as to get ecofriendly and sustainable development of aquaculture sector. Various research institutions have developed various techniques to enhance per hactre production, but it is necessary to assess whether the existing farmers adopted that techniques. If not, what are the constraints which inhibits the adoption of that improved techniques.

Many research findings are available regarding adoption studies in agriculture sector (Jha and Shaktawat, 1972; Sharma and Nair, 1974; Shukla, 1980; Sawant and Thorat, 1981; Nilkhade and Yowalkar, 1992; Shashikumar et al., 2000; Ranganatha et al., 2001; Khan et al., 2002; Jahagirdhar and Sundaraswamy, 2002; Shrivastava et al., 2002 and Adekule, 2003) but very few scientist have attempted to study the extent of adoption of recommended practices in fishery sectors namely capture and culture fishery.

Research findings available on adoption of improved technologies in aquaculture sector shows that production per ha was positively related with adoption behaviour of farmers. (Balasubramaniam and Perumal (1990) and Kumaran et al. (2003). Adoption studies on shrimp farming practices were not studied by any researcher in south Konkan region of India hitherto. Thus the present study is an attempt to asses the extent of adoption of 
improved techniques by the farmers of the south Konkan region (Ratnagiri and Sindhudurg district) in order to obtain sustainable yield in shrimp farming.

\section{MATERIALS AND METHODS}

The west coast of Maharashtra is known as Konkan, having $720 \mathrm{~km}$ long and $80 \mathrm{~km}$ wide strip coastal land located between Western Ghat and Arabian sea. Presently, 81 shrimp farms are in existence in the south Konkan region covering a total area of 179.95 ha, of which 45 farms are operational, 14 farms are newly constructed and remaining 22 are not in operation. The present investigation was taken up with the 45 operational farms. The data was collected by interviewing the farmers with the help of questionnaire. The combination of standard and open questionnaire was used for the present study. Questionnaire prepared to gather the needed information was categorised into general information, technical information, constraints faced by the farmers and reasons for failure of crops, if any.

Data was collected from 45 shrimp farmers by adopting census survey method along the south Konkan region, of which 18 were from Ratnagiri district and 27 from Sindhudurg district. Out of 45 respondents four farmers lost their crop due to disease outbreak and one farmer due to floods. Thus complete data was collected from 40 farmers while the general section information was collected from all the 45 farmers.

Adapting Das et al. (1988) descriptive score sheets for each of the recommended practices was constructed. A total of 16 recommended practices were used for calculation of adoption quotient. The maximum possible score to be obtained by any farmer was 32 , that is for those who adopted all the recommended practices. Scores were given according to visual observations during interviewing and response from the farmers.

Adoption behaviour of shrimp farmers was calculated by using an adoption quotient formula given by Sengupta (1967).

Adoption quotient for an individual farmer was computed from the adoption scores gained by the farmer for the adoption of improved recommended practices. On the basis of

$$
\text { Adoption quotient }=\frac{\text { Total score obtained by farmer }}{\text { Maximum score }} \times 100
$$

adoption quotient the farmers are classified into four categories as per Sengupta (1967).

$\begin{array}{ll}\text { 1. High adopters (66.67 to } 100) & \text { 2. Medium adopters (33.34 to 66.66) }\end{array}$

3. Low adopters (0 to 33.33) 4. Non-adopters (0).

\section{RESULTS}

Adoption level of shrimp farmers for improved aquaculture practices

The adoption quotient of the shrimp farmers residing in Ratnagiri and Sindhudurg districts were tabulated in Table 1.

Table 1: District-wise adoption quotient with their averages of farmers residing in the south Konkan region

\begin{tabular}{|l|l|l|l|}
\hline \multirow{2}{*}{ Adoption quotient } & \multicolumn{2}{|l|}{ District } & \multirow{2}{*}{ Total } \\
\cline { 2 - 4 } & Ratnagiri & Sindhudurg & \\
\hline Minimum & 50 & 53.13 & 50 \\
\hline Maximum & 96.88 & 96.88 & 96.88 \\
\hline Average & $72.06 \pm 4.0973$ & $78.67 \pm 2.6552$ & $76.18 \pm 2.3657$ \\
\hline
\end{tabular}


Journal Of Agriculture and Social Research (JASR) Vol. 6, No.2, 2006

The adoption quotient obtained by the shrimp farmers ranged from 50 to 96.88 with the mean of 76.18 (S. E. $= \pm 2.3657$ ).

Table 2: Distribution of shrimp farmers according to level of adoption of improved aquaculture practices

\begin{tabular}{|l|l|l|l|l|l|l|}
\hline \multirow{2}{*}{ Level of adoption } & \multicolumn{4}{l}{ District } & \multicolumn{2}{l}{ Total } \\
\cline { 2 - 7 } & \multicolumn{2}{|l|}{ Ratnagiri } & \multicolumn{2}{l}{ Sindhudurg } & \multicolumn{2}{l|}{} \\
\cline { 2 - 7 } & No. & \% & No. & $\%$ & No. & \% \\
\hline High adoption & 8 & 47.06 & 16 & 69.57 & 24 & 60.00 \\
\hline Medium adoption & 9 & 52.94 & 7 & 30.43 & 16 & 40.00 \\
\hline Low adoption & 0 & 0.00 & 0 & 0.00 & 0 & 0.00 \\
\hline No adoption & 0 & 0.00 & 0 & 0.00 & 0 & 0.00 \\
\hline
\end{tabular}

From Table 2, it is observed that $60 \%$ of shrimp farmers fell in the category of high level of adoption and 40\% shrimp farmers fall in category of medium level of adoption along the south Konkan region. This showed that most of the farmers were high adopters of the improved aquaculture practices. In Ratnagiri district, $47.06 \%$ of farmers were high adopters and the remaining $52.94 \%$ were medium adopters whereas $69.57 \%$ of farmers were high adopters and $30.43 \%$ farmers were medium adopters in Sindhudurg district.

Practice-wise extent of adoption for improved aquaculture techniques

The extent of adoption for improved aquaculture techniques of shrimp farmers in the south Konkan is depicted in Fig. 1.

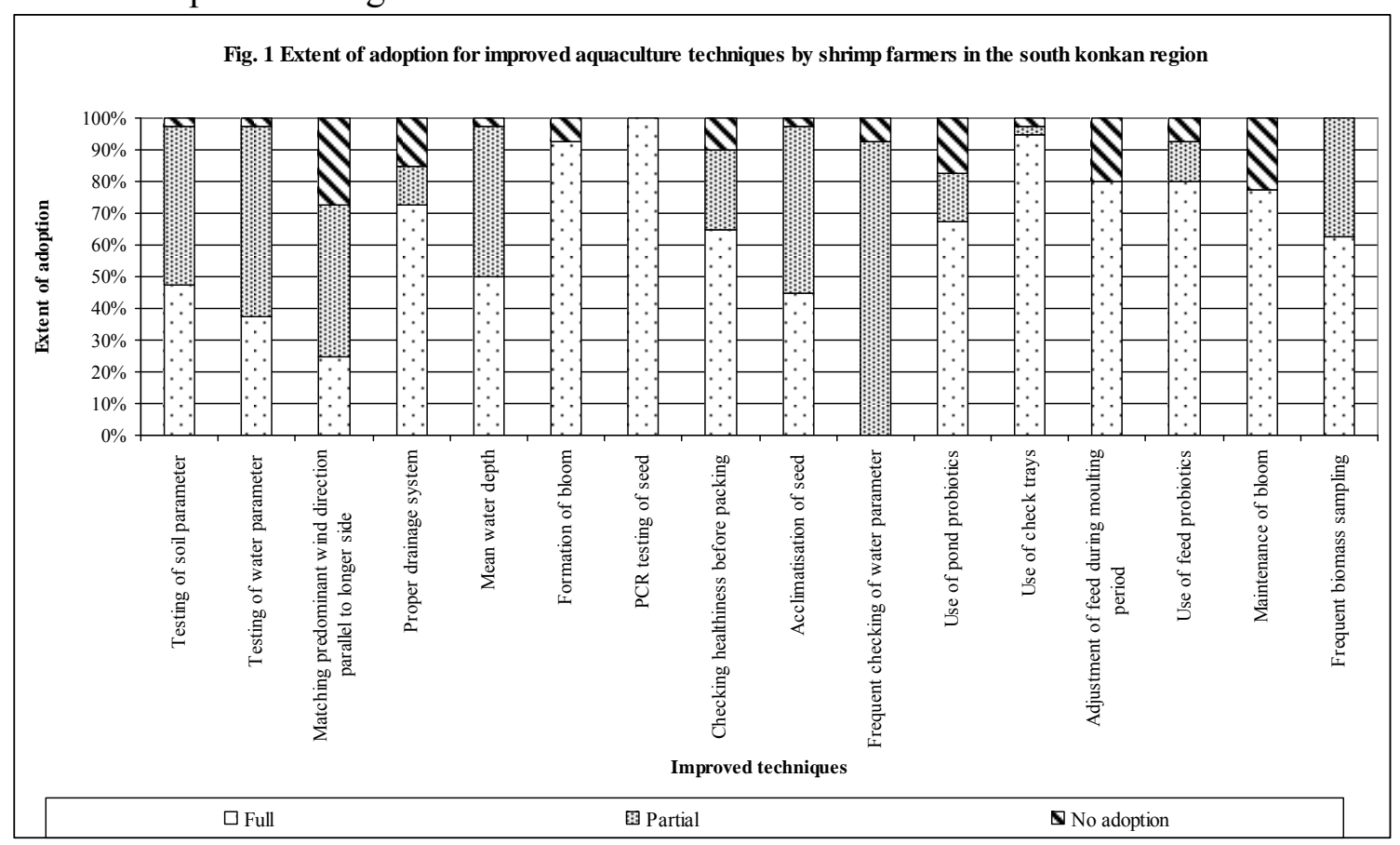

The results showed that all the shrimp farmers adopted PCR-testing of seed. From Fig. 1 that there was quite high extent of adoption for some of the practices such as use of check trays and adjustment of feed accordingly (95.0\%), formation of bloom in colour range of brownish to yellowish before stocking $(92.5 \%)$, use of feed probiotics (80\%), adjustment of feed during to lunar cycle or moulting period (80\%) and maintenance of bloom $(77.5 \%)$. It 
was also seen that there was quite high partial adoption among the shrimp farmers with respect to frequent checking of water parameters $(82.5 \%)$, checking of healthiness of seed before packing $(72.5 \%)$.

District-wise extent of adoption of improved aquaculture techniques is shown in Fig. 2 for Ratnagiri district and Fig. III for Sindhudurg district.
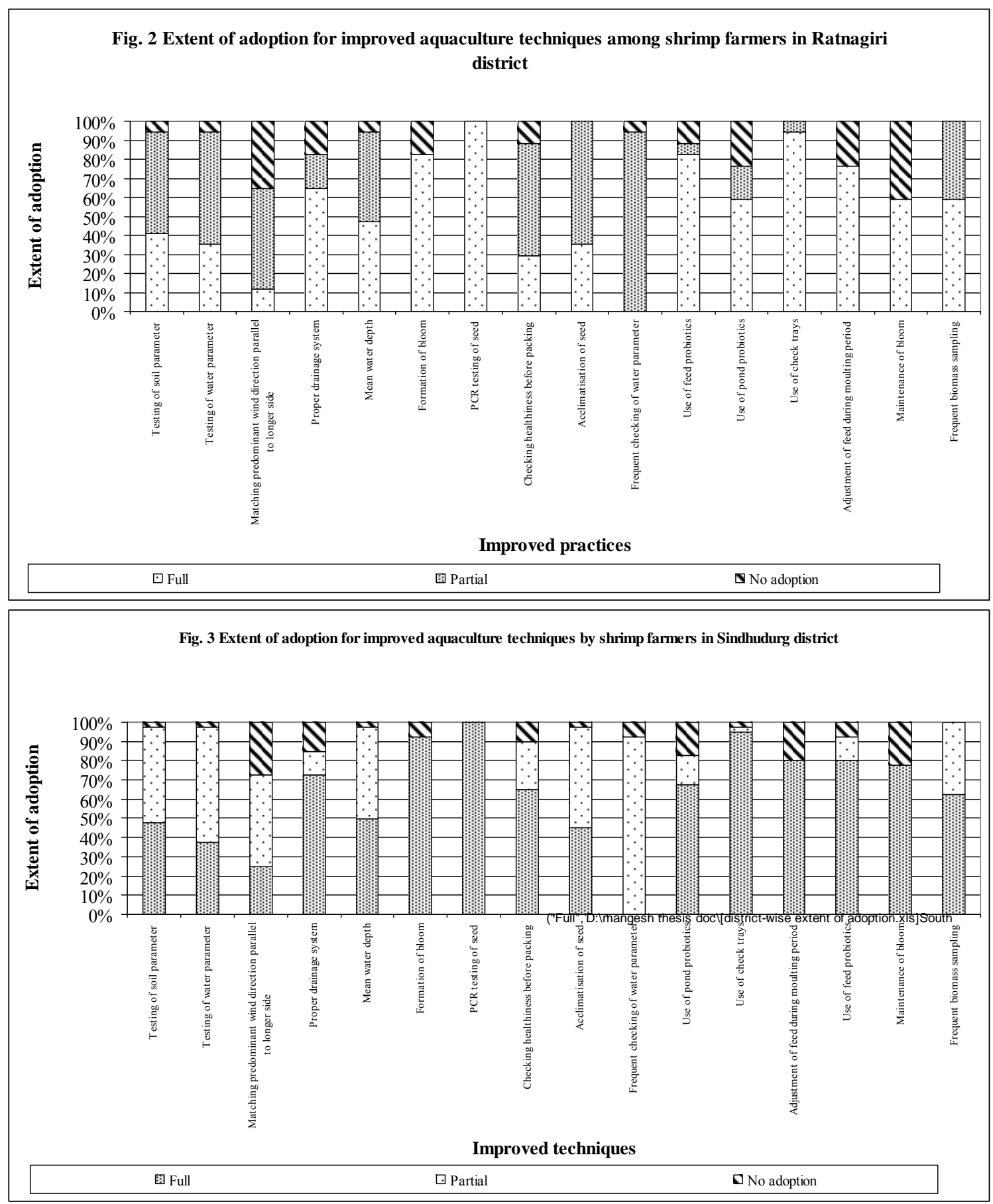

In Ratnagiri district, most of the shrimp farmers adopted the PCR-testing (100\%), use of feed probiotics $(82.35 \%)$, formation of bloom $(82.35 \%)$. There was high percentage of partial adoption towards frequent checking of water parameters $(94.12 \%)$ during culture operation, acclimatisation of seed (64.71\%). The shrimp farmers from Sindhudurg district were with cent percent adopters of practices such as formation of bloom and PCR-testing of seed. Along with these practices, farmers from Sindhudurg district adopted practices such 
have use of check tray and adjustment of feed accordingly (95.65\%), maintenance of bloom $(91.30 \%)$, adjustment of feed during moulting period $(82.61 \%)$. Improved practices as checking of healthiness of seed before packing $(91.30 \%)$ and frequent checking of water parameters $(82.61 \%)$ were adopted partially by the shrimp farmers of Sindhudurg district.

\section{Adoption behaviour and adoption quotient}

Adoption behaviour of farmers for improved aquaculture practices

Frequency distribution table was constructed for each of improved aquaculture techniques under study by classifying the farmers according to score gained by each farmer for a particular practice. Binomial distribution was constructed to get expected frequency for each category for each of the recommended practices. The significance for each recommended practice was tested. The chi-square values for adoption behaviour of improved aquaculture techniques are given in Table 3.

Table 3: Chi-square statistics of adoption behaviour of shrimp farmers

\begin{tabular}{|c|c|c|}
\hline Sr. No. & Improved practices & Chi-square value \\
\hline 1 & Testing of soil parameters & 05.14 \\
\hline 2 & Testing of water parameters & $12.82 *$ \\
\hline 3 & $\begin{array}{l}\text { Matching predominant wind direction parallel to } \\
\text { longer side of the pond }\end{array}$ & 00.10 \\
\hline 4 & Proper bottom slope for drainage of water & $13.81 *$ \\
\hline 5 & Mean water depth 1.2 to $1.5 \mathrm{~m}$ & 03.89 \\
\hline 6 & $\begin{array}{l}\text { Formation of bloom in colour range of brownish to } \\
\text { yellowish before stocking }\end{array}$ & $43.57 *$ \\
\hline 7 & PCR testing of seed for presence of WSSV & $40.00 *$ \\
\hline 8 & $\begin{array}{l}\text { Checking healthiness of seed before packing for } \\
\text { transportation }\end{array}$ & $11.02 *$ \\
\hline 9 & Acclimatisation of seed & $06.63 *$ \\
\hline 10 & Frequent checking of water parameter & $29.83 *$ \\
\hline 11 & Use of feed probiotics & $17.14 *$ \\
\hline 12 & Use of pond probiotics & 04.47 \\
\hline 13 & $\begin{array}{l}\text { Use of check trays and adjustment of feed } \\
\text { accordingly }\end{array}$ & $22.00 *$ \\
\hline 14 & $\begin{array}{l}\text { Adjustment of feed according to lunar cycle or } \\
\text { moulting period }\end{array}$ & 05.86 \\
\hline 15 & Maintenance of bloom for initial two months & $19.06 *$ \\
\hline 16 & $\begin{array}{l}\text { Pond biomass sampling with cast net at every 7-15 } \\
\text { days }\end{array}$ & 00.61 \\
\hline
\end{tabular}

* Significant at $\mathrm{P}<0.05$

The recommended practices such as use of check trays and adjustment of feed accordingly as well as pond biomass sampling with cast net at every $7-15$ days were not 
significantly different $(\mathrm{P}>0.05)$ from expected distribution whereas all other practices were significantly different from expected values $(\mathrm{P}<0.05)$.

\section{DISCUSSION}

In fishery sector, aqua-farming particularly that of brackish water shrimp farming is gaining rapid attention because of stagnation in capture fishery and heavy demand for shrimp both in domestic as well as export markets. So, many entrepreneurs are already venturing over into this business because of high returns on investment of this industry despite heavy investment.

The adoption quotient of the shrimp farmers operated along the south Konkan regions ranged from 50 to 96.86 with a mean of $76.18 \pm 2.3637$. All the farmers of the south Konkan were categorised into high and medium adopters. None of the farmer was in the category of low and no adoption. The percentage of high adopters was $60 \%$ in the south Konkan region. District-wise, Sindhudurg farmers were having higher adopters $(69.57 \%)$ than that of Ratnagiri district (47.06\%).

The extent of adoption of each of the practices would give an idea about level of adoption of shrimp farmers residing in the south Konkan region. Testing of soil and water parameters before site selection was adopted by less than $50 \%$ of farmers. Balasubramaniam (1990) observed that $65 \%$ of respondents were not adopting testing soil and water parameters before construction of farm in case of composite fish culturist in Tamilnadu whereas Kumaran et al. (2003) observed that 57.5\% of shrimp farmers have adopted recommendation in regards to site selection. Similar type of behaviour was also observed among shrimp farmers of the south Konkan region. Most of the farmers were checking sand-silt-clay percentage, water holding capacity and soil $\mathrm{pH}$ but heavy metals and organic carbon were not tested. Similar type of partial adoption was observed in case of testing of water parameters. The parameter tested regularly by majority of farmers were $\mathrm{pH}$, salinity, transparency and colour of water. The reason for partial adoption may be unavailability of soil and water testing laboratory in near by areas or as farmers were not in position to purchase due to high cost of soil and water parameter testing kits. So it can be inferred that the farmers were testing only those parameters, which were possible to estimate with low cost kits or equipments.

The technique of matching of predominant wind direction parallel to lengthier side of pond to facilitate natural aeration was followed by $25 \%$ farmers fully and partially by $47.5 \%$ farmers of the south Konkan region. Proper slope of pond for drainage of water was considered by $72.5 \%$ of farmers. The proper slope of pond minimises the time required to drain the pond completely with accumulated waste. The recommended mean depth of pond was followed only by $50 \%$ of farmers. The reasons for high percentage of partial or no adoption of improved techniques regarding pond construction may be due to unavailability of technical manpower for pond construction or unawareness of the techniques at the time of construction of farm.

Formation of bloom in colour range of brownish to yellow before stocking of seed was adopted by $92.5 \%$ of farmers along the south Konkan region. This practice was adopted by cent percent shrimp farmers in Sindhudurg district. Kumaran et al. (2003) reported similar type of observation while Vishwakumar (1992) observed that the farmers of Andhra Pradesh did not adopt preferential blooming of desirable plankton. The reason for high adoption of this technique was the awareness about the bloom formation and it's importance in stabilization of water quality, lowering of toxic component concentration, maintenance of temperature and it improve the FCR due better productivity.

Stocking of PCR-tested seed was adopted by all the farmers operated along the south Konkan region. This finding were similar to Kumaran et al. (2003) and contrary to the finding of Srinath (1996). The shrimp industry observed heavy losses due to WSSV in mid nineties, therefore, farmers were taking due care for prevention of WSSV by stocking PCR- 
tested seed. Acclimatisation of seed before stocking were adopted by almost all the farmers $(97.5 \%)$ but to the varying extent. Scientific acclimatisation of seed before stocking was carried out by $45 \%$ of the farmers by recording difference in parameters of seed transported water and pond water whereas $52.5 \%$ of farmers did not observe the actual acclimatisation technique because of unawareness.

Frequent checking of water parameters during culture operation was not fully adopted by most of the farmers $(10 \%)$. This finding were similar to Srinath, (1996) and contrary to Kumaran et al. (2003). The water quality parameters monitoring were limited to parameters like salinity and $\mathrm{pH}$ only. This observations were similar to that of Vishwakumar, (1992) in case of farmers of Andhra Pradesh. The unavailability of water parameter testing laboratory in near by vicinity and unawareness about importance of checking other parameters may be the reasons of high percentage of partial adoption. Maintenance of bloom in culture pond was adopted by $77.5 \%$ of shrimp farmers along the south Konkan. This observations were contrary to the observations of Viswakumar, (1992). Use of probiotics for water quality maintenance is of recent development and was adopted by $67.5 \%$ of farmers operating along the south Konkan.

Use of check trays and adjustment of feed accordingly was followed by almost all farmers (95\%). There are no comparable results available to support these observations. Use of check trays and adjustment of feed accordingly reduces the pollution of pond water and also improves the profit through better food conversion ratio as cost of feed contributes 40$45 \%$ of total variable cost. Use of feed probiotics has been adopted by $80 \%$ of farmers of the south Konkan region. These findings were inline with findings of Kumaran et al. (2003). Use of antibiotics for treatment of diseased shrimp was banned by Aquaculture Authority of India and it has suggested to employ feed probiotics as an alternative to antibiotics for health management of shrimp. These may be the reason for high adoption of this improved technique. Adjustment of feed according to moulting period was adopted $77.5 \%$ of farmers along the south Konkan. These findings were similar to Kumaran et al. (2003). Normally feeding was dropped during moulting period and increased after post moulting period. Proper precautions during moulting period would help in maintaining good soil and water conditions of pond and it helps in improvement of FCR by reducing feed losses during moulting period.

All farmers in varying extent adopted pond biomass sampling with cast net. These findings were similar to the findings of Balasubramaniam and Perumal (1990). They have reported adoption of biomass sampling in composite fish culture and Kumaran et al. (2003) reported that $100 \%$ farmers were doing sampling and biomass estimation.

\section{CONCLUSION AND RECOMMENDATIONS}

It can be concluded from the present study that the shrimp farmers of this region have learnt lesson from the mistakes of earlier entrepreneurs who have faced heavy losses during mid nineties due to out break of WSSV disease in Andhra Pradesh and Tamilnadu. So, shrimp farmers from the south Konkan region showed better adoption of most of the improved techniques for development of eco-friendly and sustainable aquaculture practices. Therefore if farmers are continue to worked in this pattern then surely we can get good aquaculture production from south Konkan region for years and it would help to improved socioeconomic status of farmers operating along south Konkan region with increased per ha production.

\section{REFERENCES}

Adekunle, O. A., Ogunlade, I. and Oladele, O. I., 2003. Adoption of soyabean production technology in Kwara state, Nigeria. Journal of Extension systems, 19 (2): 32-35. 
Balasubramanium, S., and G. Perumal 1990. Adoption behaviour of and impact of technology transfer among fish farmers. Fish. Technol., 27: 75-78.

Das, P., U. Bhaumik, P. K. Pandit, B. K. Banerjee and S. K. Mondal 1988. Some variables contributing to the adoption of composite fish culture innovations. In M. Mohan Joseph (Ed.). The First Indian Fisheries Forum Proceedings. Asian Fish. Soc., Indian Branch, Manglore: 467-470.

Jahagirdar, A. K. and Sundaraswamy, B., 2002. Adoption of recommended practices of Tomato cultivation. Agriculture Extension Review, 14 (2): 12-16.

Jha, P.N. and Shaktawat, G. S., 1972. Adoption behaviour of farmers towards hybrid bajra cultivation. Indian Journal of Extension Education, 8 (1 and 2): 24-29.

Khan, M. S., Krishna, T. and Punna Rao, P., 2002. Adoption pattern of Eco-friendly technologies by rice growers. Agriculture Extension Review, 14 (2): 22-25.

Kumaran, M., K. Ponnusamy and N. Kalamaimani 2003. Diffusion and adoption of shrimp farming technologies. Aquacul. Asia., 8: 20-23.

Lokare, K. V., Sivarajan, K. and Mohapatra, U. C., 2002. Present status of shrimp farming of Maharashtra (abstract). In: National seminar on Low Cost Aquaculture Technology held at College of Fisheries, Ratnagiri on 13-14 December, 2002: 29.

Nilkhade, D. M. and Yawalkar, P. B., 1992. Adoption of plant recommendations by orange growers. PKV Research Journal, 19 (1): 110-111.

Ranganatha, A. D., Veerabhadriah, V. and Lalitha, K. C., 2001. Adoption of organic farming practices by small farmers. Agriculture Extension Review, 13.

Sawant, G.K. and Thorat, S.S., 1981. Characteristics of Adopters of farm practices. Journal of Maharashtra Agriculture University, 6 (3): 236-241.

Sengupta, T. 1967. A simple adoption scale for farmers for high yielding varieties of paddy. Indian Jour. of Exten. Edu., 3: 107-115.

Sharma, S. K. and Nair, G.T., 1974. A multivariable study of adoption of high yielding varieties of paddy. Indian Journal of Extension Education, 10 (1 and 2): 30-35.

Shashi kumar, S., Hirevenkanagoudar, L.V. and Nagaraja, M. V., 2000. Understanding and adoption level of various soil and water conservation practices by farmers. Agriculture Extension Review, 12 (3): 28-31.

Shrivastava, K. K., Trivedi, M. S. and Lakhera, M. L., 2002. Knowledge and adoption behaviour of chili growers. Agriculture Extension Review, 14 (4): 22-25.

Shukla, S.R., 1980. Adoption behaviour of small farmers. Indian Journal of Extension Education, 16 (1 and 2): 55-58.

Srinath, K. 1996. Adoption of shrimp culture practices by farmers. Seafoos Exp. J., 27(10): 912.

Vishwakumar, M. 1992. Technical and economical considerations for shrimp culture in Andhra Pradesh. Fish. Chimes., 12(6): 30-40. 